\title{
Oil Prices and the Real Exchange Rate in Nigeria
}

\author{
Victor E. Oriavwote ${ }^{1} \&$ Nathanael O. Eriemo ${ }^{2}$ \\ ${ }^{1}$ Department of Arts and Social Sciences, Delta State Polytechnic, Otefe-Oghara, Nigeria \\ ${ }^{2}$ Department of Economics, Faculty of Social Sciences, Delta State University, Abraka, Nigeria \\ Correspondence: Victor E. Oriavwote, Department of Arts and Social Sciences, Delta State Polytechnic, \\ Otefe-Oghara, Nigeria. Tel: 80-3581-4123. E-mail: oriavwote40@yahoo.com
}

\author{
Received: March 29, 2012 \\ Accepted: April 29, 2012 \\ Published: June 1, 2012 \\ doi:10.5539/ijef.v4n6p198 \\ URL: http://dx.doi.org/10.5539/ijef.v4n6p198
}

\begin{abstract}
This paper has investigated the relationship between the real oil prices and the Real Exchange Rate. Using time series data covering the period between 1980 and 2010, the result of the Johansen cointegration test suggests a long run equilibrium relationship between the real oil prices and the Real Exchange Rate. This relationship was supported by the Granger Causality test which validated the causal relationship from the real oil prices to the Real Exchange Rate. The result from the Generalized Autoregressive Conditional Heteroskedasticity test suggests persistence of the volatility between the real oil prices and the Real Effective Exchange Rate. The implication of this is that government policies in tackling the impact of fluctuations in real oil prices are important source of stabilizing the movements in the Real Effective Exchange Rate. The Nigerian government should consider this important relationship when formulating and implementing economic policies.
\end{abstract}

Keywords: real exchange rate, real oil pries, vector error correction, the Nigerian economy

\section{Introduction}

The Real Exchange Rate (RER) is a significant factor in the development process of an economy as both its level and stability are important in increasing exports and private investment. Globally, the price of oil has been a significant determinant of the level of economic performance. The magnitude of the direct effect of a given oil price increase depends on the share of the cost of oil in national income, the degree of dependence on imported oil and the ability of end-users to reduce their consumption and switch away from oil (Marzieh, 2006). Since oil is the main stay of the Nigerian economy, the price of oil plays a vital role in shaping the economic well being of the country. The price of oil has witnessed signifincat fluctuations since 1974. For instance, it oscillated between $\$ 17$ per barrel and $\$ 26$ at different times in 2002 and about $\$ 53$ per barrel by October 2004 (Philip and Akintaye, 2006). Between 2000 and 2008, oil prices increased more than 6 folds from $\$ 23$ per barrel in January 2000 to a peak at an all time high at $\$ 146$ per barrel in July 2008 before crashing to $\$ 42$ per barrel by December of 2008. for the year 2009, oil price averaged $\$ 61.73$ per barrel (Hassan and Zamid, 2011). The price of oil has continued to trend upward as result of the political crisis in the Middle East, particularly, the revolutions in some Arab countries including Tunisia, Egypt, Libya, Yemen and Syria as well as the Iranian nuclear crisis which led to a ban of the import of Iranian oil by U.S.A and European countries and threats of repercussion from Iran.

The transmission mechanism through which oil prices influence the RER include both supply and demand channels. The supply side effects are related to the fact that crude oil is a basic input in production and consequently, an increase in oil price leads to a rise in the cost of production of non-tradable goods. The price of non-tradable goods will thus increase leading to an appreciation of the RER. The RER is also indirectly affected through its relation with disposable income. A rise in oil price reduces the consumers spending power. This will reduce the demand for non-tradables and therefore to a fall in their prices. This will depreciate the RER. The Nigerian oil sector can be categorized into three segments- upstream, downstream and gas. However, the downstream sector provided the most challenge. The incessant crisis in supply of petroleum products culminated in the government's decision to deregulate the downstream sub-sector. Oil production by the Joint Venture companies accounts for about $95 \%$ of Nigeria's crude oil production. Shell which operates the largest joint venture with $55 \%$ government interest, through the Nigerian National Petroleum Corporation, NNPC) produces about $50 \%$ of Nigeria's crude oil, Exxon Mobil, Chevron Texaco, ENI.AGIP and Totalfinal Elf operated the other Joint Ventures (Gbadebo, 2007).

Lots of empirical studies have been carried out on oil prices and the RER in the developed countries (Clarida and Gali, 1995, Chaudhuri and Daniel, 1998, Chen and Chen, 2007, Spatafora and Stavrev, 2003, Bjornland and 
Hungnes, 2008, Akram, 2004 and Habib and Kalamova, 2007).However, only few studies have been carried out on oil and RER (Ozsoz and Akinkunmi, 2011 and Hassan and Zahid, 2011) in developing countries including Nigeria. Thus despite the general recognition that oil plays an important role in the Nigerian economy, little research exists on the effects of oil prices on the RER. Thus a study that investigates oil prices and RER will have direct relevance for policy purpose. The study will shed new light and add to what is already known regarding this relationship in the less developed countries and Nigeria in particular.

The Nigerian economy is exposed to oil price shocks since oil contributes over $90 \%$ of the total revenue. This shock is so severe that the Nigerian budget is even tied to a particular price of crude oil and the budget was adjusted in some occasions when there is a sudden change in crude oil price such as the reduction of budget due to a fall in oil prices during the las global financial crisis. This is even worsened due to the fact that despite the four refineries, Nigeria is still exposed to oil price shocks due to massive importation of refined petroleum products. As an oil exporter and importer of refined products, Nigeria is thus vulnerable to oil price volatility. The main purpose of this paper is thus to examine empirically how the RER in Nigeria responds to volatility in oil prices. A Vector Error Correction and Variance decomposition models of the Nigerian economy will be estimated for this study. Other than this introductory section, the rest of the paper is divided into four sections. The second section is on the theoretical underpinnings and the third section is on the review of relevant empirical literatures. The statistical procedures form the fourth section and the fifth section concludes this paper.

\section{Theoretical Underpinnings}

The theoretical framework is based on Chen and Chen (2007). Suppose that the home and foreign country consumer price indices be as follows:

$$
\begin{gathered}
\mathrm{CP}_{\mathrm{n}}=\left(\mathrm{P}^{\mathrm{t}}\right)^{\mathrm{a}}\left(\mathrm{P}_{\mathrm{n}}\right)^{1-\mathrm{a}} \\
\Rightarrow \mathrm{P}_{\mathrm{t}}=\log \left(\mathrm{CP}_{\mathrm{n}}\right)=\alpha \log \left(\mathrm{P}^{\mathrm{t}}\right)+(1-\alpha) \log \left(\mathrm{P}^{\mathrm{n}}\right) \\
\Rightarrow \mathrm{P}_{\mathrm{t}}=\alpha \mathrm{P}_{1}^{\mathrm{t}}+(1-\alpha) \mathrm{P}_{\mathrm{t}}^{\mathrm{n}} \\
\mathrm{CP}_{\mathrm{f}}=\left(\mathrm{P}^{\mathrm{t}^{*}}\right)^{\alpha^{*}}\left(\mathrm{P}^{\mathrm{n}^{*}}\right)^{1-\alpha} \\
\Rightarrow \mathrm{P}_{\mathrm{t}}^{*}=\log \left(\mathrm{CP}_{\mathrm{f}}\right)=\alpha^{*} \log \left(\mathrm{P}^{\mathrm{t}^{*}}\right)+\left(1-\alpha^{*}\right) \log \left(\mathrm{P}_{\mathrm{t}}^{\mathrm{n}}\right) \\
\Rightarrow \mathrm{P}_{\mathrm{t}}^{*}=\alpha+\mathrm{P}_{1}^{\mathrm{t}^{*}}+(1-\alpha) \mathrm{P}_{1}^{\mathrm{n}^{*}}
\end{gathered}
$$

Where $\mathrm{P}_{1}{ }^{\mathrm{t}}\left(\mathrm{P}_{1}{ }^{\mathrm{t}^{*}}\right)$ and $\mathrm{P}_{1}{ }^{\mathrm{n}}\left(\mathrm{P}_{1}{ }^{\mathrm{n}^{*}}\right)$ are prices of traded and non-traded goods in the home (foreign) country, while $\mathrm{CP}_{\mathrm{n}}$ and $\mathrm{CP}_{\mathrm{f}}$ are home and foreign consumer price indices, respectively. $\alpha$ and $\alpha^{*}$ weights correspond to the expenditure shares on traded goods near the point of approximation for the home and foreign countries. The log of the exchange rate, is defined as:

$$
\begin{aligned}
& \mathrm{q}_{\mathrm{r}}=\underline{\mathrm{p}}_{\mathrm{P}}^{\mathrm{q}} \mathrm{q}_{\mathrm{n}} \\
& \Rightarrow \log \left(\mathrm{q}_{\mathrm{r}}\right)=\log \left(\mathrm{q}_{\mathrm{n}}\right)+\log \left(\mathrm{P}^{*}\right)-\log (\mathrm{p}) \\
& \Rightarrow \mathrm{lq}_{\mathrm{r}}=\mathrm{lq}_{\mathrm{n}}+\mathrm{P}_{\mathrm{t}} *-\mathrm{P}_{\mathrm{t}}
\end{aligned}
$$

Where $\mathrm{q}_{\mathrm{r}}$ and $\mathrm{q}_{\mathrm{n}}$ are real and nominal exchange rates, respectively. Thus, from (1), (2) and (3), the real exchange rate can be written as:

$$
\begin{gathered}
\mathrm{lq}_{\mathrm{r}}=\left(\mathrm{lq}_{\mathrm{n}}+\mathrm{P}_{1}^{\mathrm{t}^{*}}+\mathrm{P}_{1}{ }^{\mathrm{t}}\right) \\
+(1-\alpha)\left(\mathrm{P}_{\mathrm{t}}^{\mathrm{t}}-\mathrm{P}_{\mathrm{t}}^{\mathrm{n}}\right) \\
-\left(1-\mathrm{a}^{*}\right)\left(\mathrm{P}_{\mathrm{t}}^{\mathrm{t}^{*}}-\mathrm{P}_{\mathrm{t}}^{\mathrm{n}^{*}}\right)
\end{gathered}
$$

According to (4), if $\alpha \cong \alpha^{*}$ a rise in the relative price of domestic tradables, depreciates the RER, while the magnitude of the rise exceeds that of the rise in the relative price of foreign tradables. That is, if the home country is more dependent on imported oil, a real oil ice rise may increase the prices of tradable goods in the home country by a greater proportion than in the foreign country, and thereby cause a real depreciation of the home currency. Moreover, in order to improve competitiveness when an oil price shock worsens the term of trade, the home country would have to raise the nominal exchange rate, which would lead to a further real depreciation.

\section{Empirical Literature}

Clarida and Gali (1994) assessed the sources of RER fluctuations using Blanchard-Quah identification strategy in US-Canada, US-Germany, US-Japan and US-UK RER data from the third quarter in 1974 to the fourth quarter of 
1992. their study showed that real shocks account for more than 50 percent of the variance of RER. Chaudhuri and Daniel (1998) in their study of long run equilibrium RER for 16 OECD countries and found that the non-stationary behaviour of US dollar RER is due to the non-stationary behaviour of real oil prices. Cashin, Luis and Sahay (2004) in their study of over 50 countries discovered a long run relationship between exchange rate and the exported commodity price in one third of the sample. Yousefi and Wirjanto (2004) empirically investigated the role of the exchange rate on crude oil price formation among OPEC member countries and the US dollar against other major countries and prices of other members. The results highlighted a cross-regional dimension of the crude oil market. Chen and Chen (2007) investigated the long run relationship between real oil prices and RER by using a monthly panel for G7 countries and then found that real oil prices may have been the dominant source of RER movements and that there is a link between real oil prices and RER. Aziz (2009) in a comparative study between net oil exporters and oil importers found evidence of a statistically significant relationship between oil prices and RER and found no evidence of along run relationship between RER and oil prices. Leili (2010) investigated the long run relationship between real oil prices and RER using monthly panel data of seven countries of OPEC members from 2000 to 2007. The result showed that real oil prices may have been the dominant source of RER movements. The result also showed a long run linkage between real oil prices and the RER. In a study of the long run relationship between real oil prices, Real Effective Exchange Rate (REER) and productivity differentials. Hassan and Zahid (2011) using annual data for Nigeria covering 1980 to 2010, found that whereas real oil prices exercise a significant positive effect on the RER in the long run Productivity differentials exercise a significant negative influence on the RER. Ozsoz and Akinkunmi (2011) investigated the price based determinants of the Nigerian RER. They showed the positive effects of world oil prices on the exchange rate. Coleman, Cuestus, Maurelle and Cuestas (2011) investigated the oil price-exchange nexus using Nigeria as a case study found no long run relationship between REER and real oil prices for Nigeria.

\section{VAR Modelling and the Cointegration Approach}

Vector autoregression (VAR) modelling and the cointegration approach provide not only an estimation methodology but also explicit procedures for testing the long-run relationship among variables suggested by economic theory.

According to the Granger Representation Theorem (Engle and Granger, 1987), if a P*1 vector, $X_{t}$, generated by $(\mathrm{I}-\mathrm{L}) \mathrm{X}_{\mathrm{t}}=\mathrm{d}+\mathrm{c}(\mathrm{L}) \mathrm{e}_{\mathrm{t}}$, is cointegrated, then there exists a vector autoregression (VAR), an error correction, as well as a moving average (MA) representation of $\mathrm{X}_{\mathrm{t}}$. A set of variables $\mathrm{X}_{\mathrm{t}}$, which is cointegrated, refers to the existence of long-run equilibrium relationships among economic variables (Mungule, 2004). That is, though each series may be non-stationary, there may be stationary linear combinations of the variables. The basic idea is that individual economic time series variables wander considerably, but certain linear combinations of the series do not move too far apart from each other. In economic term, there is a long-run relationship among the variables.

The most common test for cointegration is the two-step procedure of Engle and Granger (1987) which performs well for univariate tests. The first step is to fit the cointegration regression, an ordinary least squares (OLS) estimation of the static model. The second step is to conduct a unit root test on the estimated residuals. To test for cointegration is just to test for the presence of a unit root in the residuals of the cointegrating regression. If the null of a unit root is rejected, then cointegration exists. However, the long-run parameter of the cointegrating vector estimated from this approach can be severely biased in finite samples. An improved procedure of cointegration test is that which allows for more than one cointegrating vector, as suggested in Johansen (1998) and Johansen and Juselius (1990).

Following Johansen and Juselius (1990), let the $\mathrm{p}$ variables under scrutiny follow a vector autoregression of order $\mathrm{p}$ $(\operatorname{VAR}(\mathrm{p}))$ as below,

$$
\mathrm{X}_{\mathrm{t}}=\mathrm{c}+\mathrm{P}_{1} \mathrm{X}_{\mathrm{t}-1}+\ldots+\mathrm{P}_{\mathrm{P}} \mathrm{X}_{\mathrm{t}-\mathrm{P}}+\mathrm{e}_{\mathrm{t}}
$$

where, $X_{t}=n x l$ vector of economic variables in the model; $c=n x 1$ vector of constants or drift terms are innovations of this process and are assumed to be drawn from p-dimensional independently, identically distributed (i.i.d.) Gaussian distributions with covariance $\mathrm{G}$; and $\mathrm{X}_{\mathrm{P}+1}, \ldots \mathrm{X}_{0}$ are fixed.

Where;

$\mathrm{Pi}=$ nxn matrixes of time invariant coefficients, $\mathrm{i} 1, \ldots, \mathrm{p}$, and

$\mathrm{e}=\mathrm{nxl}$ vector of i.i.d. errors with a positive covariance matrix.

Let $\Delta$ represent the first difference filter. The equation can be reparameterized into the equivalent form presented below, 


$$
\begin{gathered}
\Delta X_{t}=c+P X_{t-p}+\sum_{i-0}^{p-1} \tau_{i} \Delta X_{t-i}+\tau_{t} \\
\text { Where } \tau_{t}=-\tau+\sum_{j-1}^{i} P_{j}, \quad \text { for }, \quad i=1, \ldots, p-1, p=\tau+\sum_{i}^{p} P_{j}
\end{gathered}
$$

The coefficient matrix $P$ contains information about the long-run relationships among variables. Since $e_{t}$ is stationary, the number of ranks for matrix $\mathrm{P}$ determines how many linear combinations of $\mathrm{X}_{\mathrm{t}}$ are stationary. If $0<$ Rank $(\mathrm{P})=\mathrm{r}<\mathrm{p}$, there exists $\mathrm{r}$ cointegrating vectors that make the linear combinations of $X_{t}$ to become stationary. In that case, $\mathrm{P}$ can be factored as "a" and " $\mathrm{b}$ ", with "a" and "b" being matrixes. Here "b" is a cointegrating vector that has the property that $b X_{t}$ is stationary even though $X_{t}$ itself is non-stationary and "a" then contains the adjustment parameters.

Based on an unrestricted estimation that is parameterized in terms of levels and differences, Johansen (1988) proposed likelihood ratio statistics for testing the number of cointegrating vectors. First we must solve the eigenvalues of $\left|\ddot{e}_{i} \mathrm{~S}_{\mathrm{PP}}-\mathrm{S}_{\mathrm{P} 0} \mathrm{~S}_{00}{ }^{-1} \mathrm{~S}_{0 \mathrm{P}}\right|=0$, where $\mathrm{S}_{00}$ is the moment matrix of the residuals from the ordinary least squares (OLS) regression of $\mathrm{DX}_{\mathrm{t}}$ on $\Delta \mathrm{X}_{\mathrm{t}-1} \ldots . . \Delta \mathrm{X}_{\mathrm{t}-\mathrm{P}+1} ; \mathrm{S}_{\mathrm{PP}}$ is the residual moment matrix from the OLS regression of $\Delta \mathrm{X}_{\mathrm{t}-\mathrm{P}}$ on $\Delta \mathrm{X}_{\mathrm{t}-1} \ldots \ldots \ldots \ldots \ldots \Delta \mathrm{X}_{\mathrm{t}-\mathrm{P}+1}$; and $\mathrm{S}_{0 \mathrm{P}}$ is the cross-product moment matrix. The cointegrating vector, $\mathrm{b}$, is solved out as the eigenvectors associated with the $\mathrm{r}$ largest statistically significant eigenvalues derived using two test statistics, "maximum eigenvalue statistics" and "trace statistics". The first statistic tests the hypothesis that there are $r=s$ cointegrating vectors against the alternative of $r=s+1$ by calculating the maximum likelihood test statistics as $-T . \ln \left(1-1_{s+1}\right)$, where $T$ is the sample size and $1_{s+1}$ is an estimated eigenvalue. The second statistic tests the hypothesis that there exists at most, $r$ cointegrating vectors. If the test is performed by calculating trace statistics:

$$
-T \sum_{i=r+1}^{p} \ln \{(1-\lambda i *) /(1-\lambda i)\}
$$

where $\ddot{e}_{i}{ }^{*}$ are eigenvalues obtained from cointegration analysis assuming there is no linear trend.

The model to be estimated has the REER, real oil prices measured by the domestic price of crude oil deflated by the Consumer Price Index and technological productivity measured by the growth rate of the Gross Domestic Product. The model could be linearly stated as:

$$
\text { LREER }=b_{0}+b_{1} \text { ROIP }+b_{2} \text { PRODUCTIVITY }+U t
$$

Where:

$\begin{array}{ll}\text { REER } & =\text { Real Effective Exchange Rate } \\ \text { ROIP } & =\text { Real Oil Prices }\end{array}$

\section{PRODUCTIVITY $=$ Technological Productivity}

The result of the descriptive statistics is shown in Appendix table 1.

The skewness measures the asymmetry of the distribution of the series around its mean and have values greater than 0 which indicates that the series is skewed to the right. The peakedness or flatness of the distribution was measured by the Kurtosis with an expected value of 3.0. The result in table 1 shows that the REER and real oil prices satisfy the condition. However, productivity is leptokurtic (greater than 3). The Jarque-Bera test is used to test whether the random variables are normally distributed. The Jarque-Bera test has the null hypothesis of normally distributed residuals. The result overall shows the validation of the hypothesis that the errors are normally distributed.

The test for stationarity and the order of integration among the variables were done with both the Augmented Dickey Fuller (ADF) and Phillip Peron (PP) tests. The results of both tests are shown in Appendix table 2 below: The ADF and PP unit root test results in table 2 shows that all the variables were nonstationary. They however became stationary after taken their first difference. This thus permits us to proceed to the next stage of our estimation which is the cointegration test. The summary of the Johansen cointegration test is shown in appendix table 3 below:

The result from appendix table 3 indicates the existence of a long run equilibrium relationship among the real oil prices, REER and productivity. Under this condition, favouring a Vector Autoregression (VAR) in level or first 
difference as opposed to the Vector Error Correction Model (VECM) could lead to misspecification because cointegration is established. The number of cointegrating relationship and the number of lags provided a guide for the specification of the VECM. The first step is therefore the identification of the cointegrating relationship that has been suggested in the last section. Appendix Table 4 presents the result of the VECM. A comparative assessment of the error correction term (Coint eq1) at the bottom of table 4 for the first vector shows that the REER has a t value of -3.57475 with the right negative sign. The other variables are either wrongly signed or are statistically insignificant. This suggests that the REER equation constitutes the true congregating relationship in the first vector. The result thus suggests that about 37 percent of the disequilibrium in the REER is corrected each year. The error correction term for real oil price has the right sign and falls within the acceptance region of $-1<$ error correction $<0$ but it is not statistically significant, while that of productivity measured by the growth rate of the Gross Domestic Product is statistically flawed. The result thus shows how the REER responds to variations in oil prices and productivity.

The above result was further supported by the result from the Granger causality test in Appendix table 5. The result shows the invalidation of the null hypothesis that variation in the real oil prices does not cause a change in the REER and a validation of the alternative hypothesis that variation in the real oil prices cause a change in the REER. This result supports the result of the variance decomposition.

The result from the Autoregressive Conditional Heteroskedasticity(ARCH)/ Generalized Autoregressive Conditional Heteroskedasticity $(\mathrm{GARCH})$ in appendix table 6 suggests that the volatility shocks between real oil prices and the REER are quite persistent because the summation of the ARCH(1) and GARCH(1) coefficients approximately equals unity. The implication of the result is that government policies in tackling the impact of fluctuations in real oil prices are important source of stabilizing the movements in the REER.

\section{Conclusion}

This paper assessed the link between the real oil prices and the RER in Nigeria by using time series data covering the period 1980 to 2010. The result from the ADF and PP unit root tests showed that all the variables are I(1). The cointegration results showed a long run equilibrium relationship between real oil prices and the REER. This result was supported by the result from the granger causality test which indicates a validation of the causal relationship from real oil prices to REER. The result from the GARCH test suggests the persistence of the volatility between the real oil prices and the REER. The implication of the result is that government policies in tackling the impact of fluctuations in real oil prices are important source of stabilizing the movements in the REER. Thus, the Nigerian government should consider this all important relationship between real oil prices and the REER in planning and implementation of economic policies.

\section{References}

Akram, Q. F. (2004). Oil prices and exchange rates: Norwegian evidence. Econometrics Journal, 7(2), 476-504. http://dx.doi.org/10.1111/j.1368-423X.2004.00140.x

Amano, R. A., \& Norden, S. (1998). Exchange Rates and Oil Prices. Review of International Economics, 6(4), 683-693. http://dx.doi.org/10.1111/1467-9396.00136

Aziz, M. I. A. (2009). Oil price and exchange rate: A comparative study between net oil exporting and net oil importing countries. ESDS International Annual Conference, London.

Bjournland, H. O., \& Hungnes, H. (2008). The commodity currency puzzle. The ICFAI Journal of Monetary Economics, 2, 7-30.

Camero, M., \& Tamarit, C. (2002). Oil prices and Spanish competitiveness: A cointegrated panel analysis. Journal of Policy Modeling, 24(6), 591-605. http://dx.doi.org/10.1016/S0161-8938(02)00128-X

Cashin, P., Luis, F. C., \& Saha, R. (2004). Commodity currencies and the real exchange rate. Journal of Development Economics, 75(1), 239-268. http://dx.doi.org/10.1016/j.jdeveco.2003.08.005

Chaudhuri, K., \& Daniel, B. C. (1998). Long run equilibrium real exchange rate and oil prices. Economic Letters, $58(2), 231-238$.

Clarida, R., \& Gali, J. (1994). Sources of real exchange rate fluctuations: How important are nominal shocks? Carnagie-Rochester Conference Series on Public Policy, 41.

Chen, S. H., \& Chen, H. (2007). Oil prices and the real exchange rates. Energy Economics, 29, 390-404. http://dx.doi.org/10.1016/j.eneco.2006.08.003

Coleman, S., Cuestas, J., C. Maurelle, \& E. Cuestas. (2011). Investigating the oil price-exchange nexus: Evidence from Africa. Sheffield Economic Research Paper Series SERP: 2011015 University of Sheffield, Sheffield. 
Engle, R., \& C. Granger. (1987). Cointegration and error correction: representation, estimation and testing. Econometrica, 55, 251-76. http://dx.doi.org/10.2307/1913236

Gbadebo, O. O. (2007). Crude oil and the Nigerian economic performance. Oil and Gas Business, http://www.ogbus.ru/eng/

Gujarati, D. N. (2003). Basic econometrics (4ed). New York: McGraw-Hill Inc.

Habib, M. M., \& Kalamova, M. M. (2007). Are there oil currencies? The real exchange rate of oil exporting countries, European Central Bank Working 839.

Hassan, S., \& Zahid, M. (2011). The real exchange rate of an oil exporting economy: Empirical evidence from Nigeria. FIW Working Paper 72, September.

Johansen, S. (1998). Statistical analysis of cointegration factors. Journal of Economic Dynamics and Control, 12, 23 $1-54$.

Johansen, S., \& Juselius, K. (1992). Testing structural hypothesis in a multivariate cointegration analysis of the PPP and the UIP for UK. Journal of Econometrics, 53, 211-244. http://dx.doi.org/10.1016/0304-4076(92)90086-7

Leili, N. (2010). Oil prices and exchange rates: The case of OPEC. Business Intelligence Journal, 3(1), January.

Marzieh, M. (2006). Impact of oil price on international economy, Term Paper, International Economics Master Course, Center of Excellence for Science and Innovation Studies, KTH University .

Mungule, K. O. (2004). The determinants of the real exchange rate in Zambia. African Economic Research Consortium, 146 Nairobi.

Ozsoz, E., \& Akinkunmi, M. (2011). An evaluation of price based determinants of Nigeria's real exchange rate. SSRN elibrary.

Philip, A. O., \& Akintoye, V. A. (2006). Oil price shock and macroeconomic activities in Nigeria. International Research Journal of Finance and Economics, ISSN 1450-2887 Issue 3. http://www.eurojournals.com/finance.htm.

Spatafora, N., \& Staurev, V. E. (2003). The equilibrium real exchange rate in a commodity exporting country: The case of Russia. IMF Working Paper 03/93.

Yousefi, A., \& Wirjanto, T. (2004). The empirical role of the exchange rate on the crude-oil price formation. Energy and Economics, 26, 783-799. http://dx.doi.org/10.1016/j.eneco.2004.06.001

Appendix 1. Summary of Descriptive Statistics for REER, ROIP and PRODUCTIVITY

\begin{tabular}{lccc}
\hline & LROIP & LREER & PRODUCTIVITY \\
\hline Mean & 7.893129 & 4.901208 & 0.234996 \\
Median & 8.115820 & 4.605170 & 0.053386 \\
Maximum & 10.89534 & 6.428622 & 5.505322 \\
Minimum & 1.000000 & 4.051263 & -0.070547 \\
Std. Dev. & 2.546962 & 0.692640 & 1.015096 \\
Skewness & 1.220643 & 1.012284 & 5.078870 \\
Kurtosis & 3.418128 & 2.631427 & 26.88014 \\
Jarque-Bera & 9.631577 & 5.116955 & 0.217412 \\
Probability & 0.008101 & 0.077423 & 0.000000 \\
Sum & 228.9008 & 142.1350 & 6.814897 \\
Sum Sq. Dev. & 181.6364 & 13.43300 & 28.85178 \\
Observations & 29 & 29 & 29 \\
\hline
\end{tabular}

Appendix 2. Summary of ADF and PP Unit Root Tests Results

\begin{tabular}{lllllll}
\hline Variables & \multicolumn{3}{c}{ ADF } & \multicolumn{2}{c}{ PP } \\
\hline Level & $\mathbf{1}^{\text {st }}$ Difference & Order of Integration & Level & $\mathbf{1}^{\text {st }}$ Difference & Order of integration \\
\hline REER & -1.159010 & $-5.449402 *$ & $\mathrm{I}(1)$ & -1.570192 & $-4.583432^{*}$ & $\mathrm{I}(1)$ \\
PRODUCTIVITY & -1.925375 & $-3.422332^{* *}$ & $\mathrm{I}(1)$ & -1.612792 & $-3.445278^{* *}$ & $\mathrm{I}(1)$ \\
\end{tabular}

NB: * \&** Indicate statistical significance at the $1 \% \& 5 \%$ levels respectively 
Appendix 3. Summary of Johansen Cointegration Test

\begin{tabular}{llllllll}
\hline $\begin{array}{l}\text { Hypothesized } \\
\text { No. of CE(s) }\end{array}$ & Eigen Value & Trace Statistic & $\mathbf{5 \%} \mathbf{C V}$ & $\mathbf{1 \%} \mathbf{C V}$ & Max-Eigen Statistic & $\mathbf{5 \%} \mathbf{C V}$ & $\mathbf{1 \% C V}$ \\
\hline None** & 0.996334 & 165.4241 & 29.68 & 35.65 & 151.4344 & 20.97 & 25.52 \\
At most 1 & 0.267969 & 13.98965 & 15.41 & 20.04 & 8.422178 & 14.07 & 18.63 \\
At most2 & 0.186332 & 2.56741 & 3.76 & 6.65 & 5.567474 & 3.76 & 6.65 \\
\hline
\end{tabular}

NB: Both trace and Max-eigen statistics indicate 1 cointegrating equation at both the $5 \%$ and $1 \%$ levels.

Appendix 4. Summary of Vector Error Correction Model

\begin{tabular}{|c|c|c|c|}
\hline Cointegrating Eq: & CointEq1 & & \\
\hline LREER(-1) & 1.000000 & & \\
\hline \multirow{6}{*}{ PRODUCTIVITY(-1) } & -0.035589 & & \\
\hline & $(0.07634)$ & & \\
\hline & {$[-0.46617]$} & & \\
\hline & -0.279904 & & \\
\hline & $(3.14597)$ & & \\
\hline & {$[-0.08897]$} & & \\
\hline $\mathrm{C}$ & -4.536288 & & \\
\hline Error Correction: & D(LREER) & D(LROIP) & D(PRODUCTIVITY) \\
\hline \multirow[t]{3}{*}{ CointEq1 } & -0.356758 & -0.270962 & 0.004293 \\
\hline & $(0.09980)$ & $(0.86609)$ & $(0.02320)$ \\
\hline & {$[-3.57475]$} & {$[-0.31286]$} & {$[0.18506]$} \\
\hline \multirow[t]{3}{*}{ D(LREER(-1)) } & 0.212377 & 0.304156 & -0.015855 \\
\hline & $(0.17744)$ & $(1.53990)$ & $(0.04124)$ \\
\hline & [ 1.19687$]$ & {$[0.19752]$} & {$[-0.38445]$} \\
\hline \multirow[t]{3}{*}{ D(LREER(-2)) } & 0.071168 & 2.178736 & -0.005586 \\
\hline & $(0.18222)$ & $(1.58137)$ & $(0.04235)$ \\
\hline & {$[0.39056]$} & {$[1.37775]$} & {$[-0.13190]$} \\
\hline \multirow[t]{3}{*}{ D(LROIP(-1)) } & -0.025445 & -0.258642 & -0.003010 \\
\hline & $(0.02676)$ & $(0.23224)$ & $(0.00622)$ \\
\hline & {$[-0.95081]$} & {$[-1.11369]$} & {$[-0.48394]$} \\
\hline \multirow[t]{3}{*}{ D(LROIP(-2)) } & -0.004164 & -0.145319 & 0.003398 \\
\hline & $(0.02635)$ & $(0.22868)$ & $(0.00612)$ \\
\hline & {$[-0.15801]$} & {$[-0.63546]$} & {$[0.55487]$} \\
\hline \multirow[t]{3}{*}{ D(PRODUCTIVITY(-1)) } & -0.272959 & 0.132406 & -0.002335 \\
\hline & $(0.08861)$ & $(0.76900)$ & $(0.02060)$ \\
\hline & {$[-3.08038]$} & {$[0.17218]$} & {$[-0.11339]$} \\
\hline \multirow[t]{3}{*}{ D(PRODUCTIVITY(-2)) } & -0.150249 & -0.014932 & -0.008541 \\
\hline & $(0.05938)$ & $(0.51535)$ & $(0.01380)$ \\
\hline & {$[-2.53011]$} & {$[-0.02897]$} & {$[-0.61882]$} \\
\hline \multirow[t]{3}{*}{$\mathrm{C}$} & -0.082437 & 0.338230 & 0.002111 \\
\hline & $(0.05925)$ & $(0.51416)$ & $(0.01377)$ \\
\hline & {$[-1.39141]$} & {$[0.65783]$} & {$[0.15332]$} \\
\hline R-squared & 0.495617 & 0.171360 & 0.111343 \\
\hline Adj. R-squared & 0.299468 & -0.150889 & -0.234246 \\
\hline Sum sq. resids & 1.439812 & 108.4355 & 0.077777 \\
\hline S.E. equation & 0.282824 & 2.454424 & 0.065734 \\
\hline F-statistic & 2.526736 & 0.531763 & 0.322184 \\
\hline Log likelihood & 0.724188 & -55.45717 & 38.66369 \\
\hline Akaike AIC & 0.559678 & 4.881321 & -2.358745 \\
\hline Schwarz SC & 0.946785 & 5.268427 & -1.971639 \\
\hline Mean dependent & -0.045273 & 0.116520 & 0.003502 \\
\hline S.D. dependent & 0.337911 & 2.287878 & 0.059168 \\
\hline \multicolumn{2}{|c|}{ Determinant Residual Covariance } & 0.001643 & \\
\hline \multicolumn{2}{|l|}{ Log Likelihood } & -12.98904 & \\
\hline \multicolumn{2}{|c|}{ Log Likelihood (d.f. adjusted) } & -27.33030 & \\
\hline \multicolumn{2}{|c|}{ Akaike Information Criteria } & 4.179254 & \\
\hline \multicolumn{2}{|l|}{ Schwarz Criteria } & 5.485739 & \\
\hline
\end{tabular}


Appendix 5. Result of Pairwise Granger Causality test

\begin{tabular}{llll}
\hline Sample: 1980 - 2010 & & & \\
Lags: 2 & Obs & F Statistic & Probability \\
\hline Null Hypothesis & 27 & 6.05516 & 0.04647 \\
ROIP Does Not Granger Cause REER & & 0.88127 & 0.42838 \\
REER does not Granger Cause ROIP & & \\
\hline
\end{tabular}

Appendix 6. ARCH/GARCH Result

Dependent Variable: LREER

Method: ML - ARCH (Marquardt)

Convergence achieved after 25 iterations

Variance backcast: ON

\begin{tabular}{crlrr}
\hline & Coefficient & Std. Error & z-Statistic & Prob. \\
\hline LROIP & -0.751315 & 0.115339 & -6.513956 & 0.0000 \\
C & 8.285322 & 0.540272 & 15.33546 & 0.0000 \\
\hline \multicolumn{5}{c}{ Variance Equation } \\
ARCH(1) & 0.026904 & 0.024364 & 1.104254 & 0.2695 \\
GARCH(1) & 1.272947 & 0.887895 & 1.433668 & 0.1517 \\
\hline R-squared & 0.050998 & 0.245727 & 0.207538 & 0.8356 \\
Adjusted R-squared & 0.608119 & Mean dependent var & & 4.919301 \\
S.E. of regression & 0.547830 & S.D. dependent var & & 0.672823 \\
Sum squared resid & 0.452430 & Akaike info criterion & & 0.986238 \\
Log likelihood & 5.322018 & Schwarz criterion & & 1.217526 \\
Durbin-Watson stat & -10.28669 & F-statistic & 10.08668 \\
\hline
\end{tabular}

